\title{
Monitoring organic contaminants in small French coastal lagoons: comparison of levels in mussel, passive sampler and sediment
}

\author{
Arthur David ${ }^{1,{ }^{*}}$, Elena Gomez ${ }^{1}$, Sélim Aït-Aïssa ${ }^{2}$, Morgane Bachelot ${ }^{1,3}$, David Rosain ${ }^{1}$, Claude \\ Casellas $^{1}$, Hélène Fenet ${ }^{1}$
}

\footnotetext{
${ }^{1}$ UMR 5569 HydroSciences Montpellier, Université Montpellier 1, Faculté de Pharmacie, 15 Avenue Charles Flahault, BP 14 491, 34093 Montpellier Cedex 5, France.

2 INERIS, Unit of Ecotoxicology, Parc ALATA, BP2, 60550 Verneuil-en-Halatte, France

${ }^{3}$ IFREMER, Laboratoire Environnement et Ressources LER-LR, Station de Sète, Avenue Jean Monnet 34200 Sète, France
}

*: Corresponding author : Arthur David, email address : david@msem.univ-montp2.fr

\begin{abstract}
:
In this study, the distribution of organic contaminants was investigated in the particular context of three Mediterranean coastal lagoons, where pollution input was hypothesised to come mainly from sediments resuspension. Mussels and semi-permeable membrane devices (SPMDs) were exposed to the water column for one month and then their content in estrogen-, benzo[a]pyrene- and dioxin-like substances as well as polycyclic aromatic hydrocarbons (PAH), polychlorinated biphenyls and alkylphenols was determined with biological and chemical analyses. PAH concentration was high in sediments (up to $1028 \mathrm{ng} \mathrm{g}^{-1}$ dry weight), however the aqueous PAH concentrations estimated from SPMD data could be considered below the levels inducing adverse effects according to the environmental quality standards proposed by the Water Framework Directive. Dioxin-like activity was observed in sediments but not in mussels and SPMDs. In the two sewage-impacted lagoons, nonylphenols could be quantified in sediments, SPMDs and mussels. Nonylphenol concentrations in mussels were among the highest found in the literature. However, since nonylphenols contributed only to a small part of the estrogenic activities observed, natural or synthetic steroids originating from wastewater discharges could be also implicated in these responses in sediments.
\end{abstract}




\section{Introduction}

To assess the distribution of hydrophobic organic chemicals between water, sediments and biota, the dynamic aspects of the accumulation process have to be considered. Various factors, such as biological and chemical degradation, sequestration, dispersion, and changing environmental conditions may influence the distribution processes and prevent a thermodynamic equilibrium ${ }^{1}$. Most of the studies conducted on the distribution of organic pollutants have focused on water pollution ${ }^{2-3}$ and have hypothesised that input from water is responsible for the contamination of pelagic organisms. However, it is known that hydrophobic organic pollutants bound to colloids and suspended solids, following sedimentation, remain sunk into the sediment as shown in works conducted in estuaries and bights ${ }^{4-5}$. Thus, we have previously observed ${ }^{6}$ that sediments of two Mediterranean coastal lagoons, which received effluents from sewage treatment plants (STPs) until January 2005, were contaminated by organic pollutants, such as polycyclic aromatic hydrocarbons (PAHs), alkylphenols (APs) and polychlorinated biphenyls (PCBs), even one year after the definitive stop of the sewage effluent input. These Mediterranean coastal lagoons are shallow, eutrophic areas with an important sediment resuspension rate influenced by the wind. Estimation of the distribution of organic pollutants in these ecosystems needs to take into consideration sediment as a pollution source because the particular morphology and hydrodynamics of these ecosystems lead to a significant sediment resuspension and to modifications of the flux at the sediment water interface.

Organic contaminants such as PAHs, APs or PCBs present middle to high hydrophobicity (log Kow between 4.1 and 7.2) and, therefore, tend to be rapidly adsorbed onto suspended material (i.e., sediments) and can be bioaccumulated in marine organisms ${ }^{7-8}$. Mussels are excellent sentinels for monitoring bioavailable contaminants as they can bioaccumulate them through the gills (via the dissolved phase) and/or through the digestive tracts (via the particulate phase) ${ }^{9-10}$. Furthermore, invertebrates like mussels, have been reported to show low rate of PAH metabolism ${ }^{11}$, thus allowing the unmetabolised contaminants to be accumulated at high level in the bivalves' tissues ${ }^{8}$. In addition to the use of organisms, the monitoring of lipophilic compounds can be done by passive sampling which allows obtaining time-integrated sampling and relatively high concentrations of contaminants' trace residue levels for chemical analysis. To this aim, semipermeable membrane devices (SPMDs) were developed to sample hydrophobic contaminants ${ }^{12}$. Several monitoring studies 8-13-14, laboratory exposure studies ${ }^{15}$ or oil spill assessments ${ }^{16}$ compared $\mathrm{PAH}$ concentration in mussels and SPMDs. Moreover, other contaminants, like PCBs, chlorinated pesticides ${ }^{8-17}$ and polybrominated diphenyl ethers (PBDEs) ${ }^{18}$ have been analysed simultaneously in mussels and SPMDs. These reports indicate that mussels reflect the exposure of dissolved, colloidal, and particulate contaminants (limited to a size or around $50 \mu \mathrm{m}$ ) in water, whereas SPMDs only sample the truly dissolved organic contaminants (related to limitations due to contaminants' molecular size and SPMD pore size).

In order to monitor contamination by PAHs, APs and PCBs, in vitro bioassays based on receptor-mediated reporter gene activation have been applied ${ }^{19}$ alone or in combination with chemical analysis ${ }^{20}$. Bioassays allow integrated response to all active chemicals present in complex chemical mixtures, providing a quantification of overall biological activity of sample and thus serve as a useful complement, although not a substitute, to chemical analysis. APs such as nonylphenols (NPs) and octylphenol (OP) have an estrogenic potency ${ }^{21-22}$ mediated through the estrogen receptor (ER). Planar PCBs and some PAHs activate the aryl hydrocarbon receptor (AhR) ${ }^{23-248}$. Despite the fact that SPMD characteristics and applications have been described extensively ${ }^{25-26-27}$, its use with bioassays combined to chemical analyses is relatively rare ${ }^{28-29}$.

The aim of this study was to investigate the distribution of ER and AhR activators in the particular context of Mediterranean coastal lagoons where the pollution input was hypothesised to come mainly from sediments resuspension. For this purpose, bioassays allowing the detection of estrogenic, benzo[a]pyrene-like and dioxin-like activities combined 
with chemical analysis of organic contaminants, such as PAHs, PCBs and APs, were used to evaluate the contamination of sediments as well as caged mussels and SPMDs that were deployed in the water column for one month. We then evaluated contribution of analyzed contaminants in measured biological activities.

\section{Materials and methods}

\section{Chemicals}

Solvents of pesticide grade were obtained from Carlo Erba. $\mathrm{ICl} 182,780$ and 2,3,7,8tetrachlorodibenzo-p-dioxin (TCDD) were obtained from Tocris Bioscience (Ellisville, USA) and Promochem (Molsheim, France), respectively. 17 $\beta$-estradiol (E2), nonylphenols (mixture of compounds with branched side chain, NPm), polychlorobiphenyls (PCB-set of PCB 28; 52; $101 ; 138 ; 153 ; 180 ; 10 \mathrm{ng} / \mu \mathrm{l}$ of each in iso-octane), benzo(a)pyrene (BaP) and granulated copper (grain size: 0.2-0.6 mm) were supplied by Sigma-Aldrich (St Quentin Fallavier, France). 4-tert-Octylphenol (4-t-OP), the 16 native PAHs (PAH-Mix 9, $100 \mathrm{ng} / \mu \mathrm{l}$ in cyclohexane), PCB 30, 77 and 126 were purchased from Cluzeau (Courbevoie, France). All standards were of 98.1-99.8 \% purity. Materials for cell culture were from Life Technologies (Cergy Pontoise, France). Luciferin (sodium salt) was purchased from Promega (Charbonnières, France). SPMDs filled with triolein, SPMDs spiked with performance reference compounds (PRC) and stainless steel cages were obtained from Exposmeter (Tavelsjo, Sweden). Acenaphtene d-10, fluorene d-10, phenanthrene d-10 and chrysene d12 were obtained from Supelco (St-Quentin Fallavier, France), 4-chloro[13C12]biphenyl (MBP3), 2,4'-dichloro[13C12]biphenyl (MBP8), 3,4,4'-trichloro[13C12]biphenyl (MBP37) and 2,2',6,6'-tetrachloro[13C12]biphenyl (MBP54) were supplied by Wellington INC laboratory (Irigny, France).

\section{Study area and sampling sites}

The Arnel (AL) and the Méjean (ML) lagoons are two French Mediterranean coastal lagoons with a surface of 4.75 and $5.5 \mathrm{~km}^{2}$, respectively (Fig. 1). They are characterised by shallow waters (below 1 meter) and are confined ecosystems where the wind plays a major role in their hydrodynamism. They present brackish waters due their connection to other lagoons linked to the sea. ML receives flow from the Lez River, whereas AL receives indirect flow from the Lez and the Mosson River which flows into AL. Sources of organic contamination were wastewater discharges from STPs that occurred until November 2005 as the outlet of the STP was located upstream the lagoons in the Lez River. Sampling took place in the Western part of ML and in the North-Western part of AL.

The Thau lagoon (TL) with a surface of $70 \mathrm{~km}^{2}$ is one of the largest Mediterranean lagoons located on the French Mediterranean coast. It is a shallow, semi-confined ecosystem (mean depth $4 \mathrm{~m}$ ) connected to the sea by two narrow openings located at its extremities ${ }^{30}$. The wind plays an important role in its hydrodynamics ${ }^{31}$. The source of organic contamination comes from the TL watershed (about $280 \mathrm{~km}^{2}$ ), which is drained by numerous little streams (3-13 km) with intermittent flows. Other sources of organic contamination could be maritime traffic and tourism. Sampling took place in the Western part of the lagoon.

\section{Mussels deployment and analysis}

At $A L$ and $M L$, mussels were stored in conchylicultural pouches mounted on PVC tubing ${ }^{10}$. The mussels (Mytilus galloprovincialis) came from a firm in the Languedoc-Roussillon region which harvests mussels from the open sea. Mussels were selected in order to have homogeneous batches of 150 adult mussels measuring about $50 \mathrm{~mm}$. Two batches were exposed at the 3 sites and one batch was kept as control (TO) in order to analyse mussels before exposure. At $A L$ and $M L$, the conchylicultural pouches were laid flat on a galvanized steel plate at $0.5 \mathrm{~m}$ from the bottom ${ }^{10}$. At $\mathrm{TL}$, the pouches were directly suspended from 
existing structures, $2 \mathrm{~m}$ from the surface. Mussels were exposed to the lagoon water for one month between June and July 2007. At the end of the exposure period, mussels were collected, rinsed with seawater and rapidly placed in coolers for transport to the laboratory. Mussel mortality, length and total weight were recorded. A condition index ( $\mathrm{Cl}$; unitless) equivalent to the ratio between lyophilized dry weight and shell weight of the mussel was determined for a pool of 20 randomly sampled mussels from each batch.

Histological analysis was conducted on randomly sampled mussels at T0 and after 30 days of exposure at $A L, M L$ and TL (20 mussels for each condition). The soft body of males and females mussels was fixed in Davidson's fixative, dehydrated through increasing alcohol concentrations, embedded in paraffin, sectioned $(5 \mu \mathrm{m})$ and stained with Prenant Gabe's haematoxylin-eosin. To define the different stages of the sexual maturation, the following morphological criteria ${ }^{32}$ were used during the microscopic examination: (1) indifferent stage: follicle cells can be detected in males and females; (2) development stage: proliferation of oocytes in females and spermatocytes in males; (3) ripe stage: maturation of oocytes and spermatozoa; (4) spawning stage: release of oocytes and spermatozoa and (5) rest stage: alveoli are empty. Distribution of each stage was calculated for both sexes.

Mussels to be used for chemical analysis and bioassays were frozen at $-20{ }^{\circ} \mathrm{C}$, freeze-dried, reduced to powder and homogenised. Batches of $0.8 \mathrm{~g}$ dry weight (d.w.) \pm 0.01 homogenates were then extracted twice with $20 \mathrm{ml}$ of acetone/n-heptane mixture $(1: 1$ by volume) by microwave-assisted extraction using a Multiwave 3000, Anton Paar (SAA, France). The extraction temperature was increased to $110^{\circ} \mathrm{C}$ within $10 \mathrm{~min}$ and then held for 5 min. After a 15 min cooling step, extracts and solvent were removed and the liner rinsed with $15 \mathrm{ml}$ acetone/n-heptane mixture. Extracts were then filtered through $10 \mathrm{~g}$ of anhydrous sodium sulphate and a $0.2 \mu \mathrm{m}$ filter, evaporated to dryness by rotary evaporation at $38^{\circ} \mathrm{C}$ and dissolved in methylene chloride (DCM). Extracts were topped up to $10 \mathrm{ml}$ with DCM and then filtered successively through 0.45 and $0.2 \mu \mathrm{m}$ filters before Gel Permation chromatography (GPC).

Mussel extracts were cleaned up to separate target compounds from bio-lipids using a HP 1050 high pressure liquid chromatography pump, Envirogel GPC Clean Up tandem columns of $19 \mathrm{~mm} \times 150 \mathrm{~mm}$ and $19 \mathrm{~mm} \times 300 \mathrm{~mm}$ from Waters, and a UV detector at $254 \mathrm{~nm}$. The mobile phase was DCM at a flow rate of $5 \mathrm{ml} / \mathrm{min}$. Five $\mathrm{ml}$ of each extract was injected using a $10 \mathrm{ml}$ syringe. GPC was calibrated before the runs by establishing an elution profile with a calibration solution, which consisted of corn oil, bis(2-ethylhexyl)phthalate, methoxychlor, perylene and sulphur ${ }^{33}$. A fraction of the retention time from 12 to 21 min was collected. We also checked that estradiol and ethinylestradiol (EE2) were present in the collected fraction. The calibration chromatograms were examined to ensure that the relative retention times and peak shapes were as expected. The collected fractions were reduced by rotary evaporation at $38^{\circ} \mathrm{C}$ and separated in two fractions for chemical analysis and bioassays. Extracts were evaporated to dryness under a gentle stream of nitrogen at $40^{\circ} \mathrm{C}$ and dissolved in heptane containing the internal standard for chemical analysis, or in methanol for bioassays. Blank extractions (without samples) were performed at every run.

\section{SPMD deployment and analysis}

\section{SPMD deployment and retrieval}

"Standard" low-density polyethylene (LDPE) semipermeable membranes $(91.4 \mathrm{~cm}$ in length, $2.54 \mathrm{~cm}$ in width with wall thickness ranging between 70 to $95 \mu \mathrm{m}, 0.0047 \mathrm{I}$ in volume, $4.5 \mathrm{~g}$ in mass) filled with $1 \mathrm{ml}$ of high-purity triolein (specific density $0.91 \mathrm{~g} \mathrm{per} \mathrm{cm}^{3}$ at $25^{\circ} \mathrm{C}$ ) were placed in the water in stainless steel cages. At each site, one membrane filled only with triolein and one spiked with PRCs were used. At $A L$ and $M L$, cages were fixed above the mussel pouches. At TL, the cages were directly suspended from the existing structures, $2 \mathrm{~m}$ below the surface. SPMDs were exposed, like the mussels, between June and July during 30 days. After exposure, membranes were rapidly placed in coolers at $-4^{\circ} \mathrm{C}$ and transported to 
the laboratory in tightly closed clean aluminium cans and kept at $-20{ }^{\circ} \mathrm{C}$ until the analysis. Field blank experiments were carried out during the SPMDs deployment and retrieval.

Concerning the sample processing, we used the same procedure than Huckins et al. ${ }^{34}$ for the removal of exterior biofouling and dialysis and the same procedure than Yusà et al. ${ }^{35}$ for the GPC clean-up of SPMD dialysates. Briefly, the sealed loops were removed and the surface of exposed membranes was rinsed with hexane and important biofouling removed by scrubbing with tap water. The membrane surface was rinsed with $1 \mathrm{M} \mathrm{HCl}$ and dried with acetone and isopropanol. Membranes were then rolled, inserted into glass jars with $180 \mathrm{ml}$ of hexane and dialysed for $18 \mathrm{~h}$. Dialysates were then collected, $170 \mathrm{ml}$ hexane was added into the jars and membranes dialysed for another $6 \mathrm{~h}$. Combined dialysates were rotary evaporated to a small volume (approximately $0.5 \mathrm{ml}$ ) and, after removal of the remaining solvent by gentle nitrogen stream, dissolved in $10 \mathrm{ml}$ of DCM for GPC clean up as for mussels. GPC was calibrated before the runs as described before. The collected fractions were evaporated to dryness by rotary evaporation at $38^{\circ} \mathrm{C}$, dissolved in heptane and separated in two fractions. Both fractions were evaporated to dryness under a gentle stream of nitrogen at $40^{\circ} \mathrm{C}$, one was re-dissolved in heptane with the internal standards for chemical analysis, the other in methanol for bioassays.

\section{Estimation of aqueous concentrations}

Calculation of the aqueous concentration of the analytes from the SPMD data was done using the following equation as recommended by Booij et al. ${ }^{36}$ and Huckins et al. ${ }^{37}$ :

$$
C_{w}=\frac{N}{K_{s w} V_{s}\left(1-\exp \left[-\left(R_{s} t\right) /\left(K_{s w} V_{s}\right)\right]\right.}
$$

$C_{w}$ is the aqueous concentration of the analyte (ng/l), $N$ is its amount in SPMDs (ng), $K_{s w}$ is the SPMD-water partition coefficient, $V s$ is the SPMD volume and $R_{s}$ is the sampling rate of the analyte. Since environmental factors such as velocity ${ }^{38}$ and biofouling ${ }^{39-40}$ can have noticeable effects on sampling rates, a methodology based on PRC dissipation was used to estimate the in situ $R_{s}$ of analytes. Briefly, PRCs are initially present in SPMDs and diffuse in the water. The dissipation of PRC in water corresponds to the in situ loss rate constant of the PRC $\left(k_{\text {e-PRC }}\right.$, expressed in $\left.\mathrm{d}^{-1}\right)$ calculated as follows:

$k_{\text {e-PRC }}=\ln \left(C_{S P M D o} / C_{S P M D}\right) / t$

where $\mathrm{C}_{\text {SPMDo }}$ is the initial concentration and $\mathrm{C}_{\mathrm{SPMD}}$ the remaining concentration of PRCs in SPMDs following exposure. PRC sampling rates, $R_{\mathrm{s}-\mathrm{PRC}}$, can be calculated from equation (2) 37 .

$R_{\mathrm{s}-\mathrm{PRC}}=k_{\mathrm{e}-\mathrm{PRC}} K_{\mathrm{sw}} V_{\mathrm{s}}$

Values of $K_{\mathrm{sw}}$ for non-polar compounds, such as PAHs, can be calculated from Huckins et al. 37.

$\log K_{\mathrm{sw}}=-0.1618 \log \mathrm{K}_{\mathrm{ow}}{ }^{2}+2.321 \log K_{\mathrm{ow}}-2.61$

$R_{\mathrm{S}-\mathrm{PRC}}$ can then be used to calculate in situ $R_{\mathrm{S}}$ of analyte $\mathrm{i}\left(R_{\mathrm{s}, i}\right)$ which will be

used in equation (1): 
$\alpha$ is a compound-specific effect ${ }^{37}$ modelled on the sampling rates using the results of nine laboratory calibration studies for PCBs, PAHs, Polychlorinated dibenzo-para-dioxins (PCDDs)/polychlorinated dibenzofurans (PCDFs) and pesticides:

Log $\alpha_{i}=0.0130 \log K_{o w}{ }^{3}-0.3173 \log K_{o w}{ }^{2}+2.244 \log K_{o w}$

For long term exposures ( $t>>1 / k e$ ) equilibrium is attained, and Eq. (1) reduces to

$N=C_{w} K_{s w} V_{s}$

\section{Sediment sampling and analysis}

At each site where mussels were exposed, the first $0-5 \mathrm{~cm}$ of surface sediments were sampled at least 3 times, homogenised, sieved through a $2 \mathrm{~mm}$ mesh and frozen at $-20^{\circ} \mathrm{C}$ as soon as their arrival in the laboratory. Samples were then freeze-dried, crushed and homogenized. The sediment samples were then extracted as previously described in David et al. ${ }^{6}$. Briefly, $5 \mathrm{~g} \pm 0.2$ of homogenates were weighed and extracted by microwave-assisted extraction with $30 \mathrm{ml}$ of an acetone/heptane mixture (1:1 by volume). The extraction temperature was increased to $115^{\circ} \mathrm{C}$ within $10 \mathrm{~min}$ and then held for $15 \mathrm{~min}$. For chemical analysis, $2 \times 5 \mathrm{~g}$ of each sediment sample were extracted separately and then pooled. In order to remove sulphurs, samples were incubated with $15 \mathrm{~g}$ of activated copper powder for at least 2 hours. Samples were then removed and the liner rinsed with $15 \mathrm{ml}$ acetone/heptane mixture. Samples were filtered through $10 \mathrm{~g}$ of anhydrous sodium sulphate and a $0.2 \mu \mathrm{m}$ filter, then, evaporated to dryness by rotary evaporation at $38^{\circ} \mathrm{C}$ and dissolved in heptane with the internal standard for chemical analyses or in methanol for bioassays. Blank extractions (without samples) were performed at every run. Two independent extractions were done for each sample. We also calculated sediment-based aqueous concentrations $\left(\mathrm{C}_{\text {wsed }}\right)$ as described in Verweij et al. ${ }^{41}$ :

$$
\mathrm{C}_{\mathrm{wsed}}=\mathrm{C}_{\mathrm{sed}} / \mathrm{K}_{\mathrm{oc}}
$$

$\mathrm{C}_{\text {wsed }}$ is the concentration in the sediment (we used a mean value of the two sediment extractions) based upon the organic carbon content and $\mathrm{K}_{\mathrm{oc}}$ is the sediment organic carbonwater partition coefficient, or sorption coefficient ${ }^{42}$. A steady state is assumed in this simple model between chemicals in organic matter of sediments and in the water phase. We estimated $\mathrm{K}_{\mathrm{oc}}$ values using the equation proposed by Karickhoff ${ }^{43}$.

$$
\mathrm{K}_{\mathrm{oc}} \approx 0.41 \times \mathrm{K}_{\mathrm{ow}}
$$

\section{Chemical analysis and bioassays}

\section{Gas Chromatography/mass spectrometry}

$\mathrm{PAH}, \mathrm{AP}$ and PCB chemical analysis was carried out using a GC Ultra trace 3000 (Thermo) connected to an MS detector Polaris Q (Thermo), electron impact mode, $70 \mathrm{eV}$. A ID-BPX5 capillary column ( $30 \mathrm{~m} \times 0.25 \mathrm{~mm}$ ID, with a $0.25 \mu \mathrm{m}$ film) was used. The injection of $1 \mu \mathrm{l}$ of sample was done in splitless mode. The GC temperature programmes and MS condition were previously described in David et al. ${ }^{6}$. Concentrations of each target compound were 
determined using an internal standard calibration. Injections of blank extraction did not show any contamination due to the entire procedure. The limit of quantification for each compound (estimated for a signal-to-noise ratio of 10) are presented in Table 1.

Bioassays

\section{MELN and PLHC-1 assays}

AhR-mediated activities were evaluated as previously described by Louiz et al. ${ }^{44}$ using PLHC-1 cells (ATCC, CRL-2406). Cells were routinely grown at $30^{\circ} \mathrm{C}$ in E-MEM culture medium supplemented with $10 \%$ foetal calf serum (FCS) and $1 \%$ antibiotics in a $5 \% \mathrm{CO}_{2}$ humidified atmosphere. For experiments, $5 \times 10^{4}$ cells per well were seeded in 96 -well plates. After $24 \mathrm{~h}$, cells were exposed to sample extracts for either $4 \mathrm{~h}$ or $24 \mathrm{~h}$ and then processed for measurement of ethoxyresorufin-O-deethylase (EROD) activity in intact cells, as previously described by Laville et al. ${ }^{45}$. Two different exposure times ( $4 \mathrm{~h}$ and $24 \mathrm{~h}$ ) were used in order to distinguish between effects due to $\mathrm{PAH}$-like compounds, which are rapidly metabolised by the cells, and activities due to more persistent compounds (e.g. dioxins, PCBs) that remain highly active after $24 \mathrm{~h}$ exposure.

Estrogenic activities were monitored using the MELN cell line, obtained from P. Balaguer (INSERM, U896, Montpellier, France). These cells were obtained by stably transfecting MCF7 cells with the ERE- $\beta$ Glob-Luc-SVNeo plasmid followed by selection with $1 \mathrm{mg} / \mathrm{ml} \mathrm{G} 418^{46}$. MELN cells were routinely cultured in phenol red-containing Dulbecco's Modified Eagle's Medium (DMEM), supplemented with $5 \%$ FCS, $1 \%$ nonessential amino acids and penicillin/streptomycin (50 U/ml each) in a $5 \% \mathrm{CO}_{2}$ humidified atmosphere at $37^{\circ} \mathrm{C}$. Before experiments, MELN cells were transferred to phenol red- free DMEM supplemented with $3 \%$ dextran-charcoal coated FCS (DCC medium) for two days before seeding in white opaque 96-wells culture plates $\left(10^{5}\right.$ cells per well). After $24 \mathrm{~h}$, cells were exposed to sample extracts for $16 \mathrm{~h}$. After exposure, medium was replaced with $50 \mu \mathrm{L}$ of DCC medium containing $3.10^{4}$ M D-luciferin (Sigma) and the luminescence signal in living cells was read after 5 min with a microtiter plate luminometer ( $\mu$ Beta, Wallac).

In all test conditions, the solvent concentration in the culture medium was $0.5 \% \mathrm{v} / \mathrm{v}$. At this concentration, it did not affect either cell viability or luciferase activity. Cellular viability after exposure to the different extracts was evaluated with the methyl-thiazol-tetrazolium (MTT) assay ${ }^{47}$, as previously described by Laville et al. ${ }^{45}$. No changes in cell viability were observed with any of the used dilutions. Serial dilution of organic sediment extracts and blank extracts were always tested in triplicates with a solvent control $(0.5 \% \mathrm{v} / \mathrm{v})$ and a positive control ( $1 \mathrm{nM}$ TCDD for PLHC-1 cells and $10 \mathrm{nM}$ E2 for MELN cells). Results were expressed as percentage of the maximal luciferase or EROD activity induced by the positive controls.

\section{Data analysis}

Dose-response curves of the standards (E2, TCDD and BaP) performed in every run were modelled using the Regtox 7.5 Microsoft Excel ${ }^{\mathrm{TM}}$ macro ${ }^{48}$. This macro uses the Hill's model and allows the calculation of a range of effective concentrations that generates between $5 \%$ (EC5) and $50 \%$ (EC50) of the response relative to the positive control. Dose-response curve modelling was performed when maximal activities induced by samples were above $20 \%$ (basal subtracted) of maximum response achieved for the standard. Most of the doseresponse curves for active samples were not parallel to those of the reference compounds and maximal induction varied from one sample to another. This characteristic has been previously described for other environmental samples ${ }^{49}$. Thus, in order to allow sample comparison in a given bioassay, all dose-response curves were modelled by fixing the Hill's maximal effect parameter at $100 \%$, which corresponded to the maximal effect of the reference compound and bioassay-derived equivalents (bio-EQs) were then calculated as the ratio between the EC20 of the reference substance (expressed in ng BaP, ng TCDD or 
ng $E_{2} / \mathrm{ml}$ ) and those of the sample ( $\mathrm{g}$ sediment $/ \mathrm{ml}$ ). BaP equivalents (bio-BEQs) were obtained after $4 \mathrm{~h}$ exposure of PLHC-1 cells, TCDD equivalents (bio-TEQs) after $24 \mathrm{~h}$ exposure of PLHC-1 cells and E2 equivalents (bio-EEQs) after $16 \mathrm{~h}$ exposure of MELN cells. The mean limits of quantification for sediments, mussels and SPMD for this run of experiments are defined in Table 1.

Chemical equivalents derived from instrumental analysis (chem-EQs) were calculated according to the following equation:

$$
\text { Chem-EQ }=\Sigma\left(\left[\mathrm{C}_{i}\right] \times \mid \mathrm{IF}_{i}\right) \text {, }
$$

where $\left[C_{i}\right]$ is the measured concentration of the compound (i) in the sample and $I E F_{i}$ is the induction equivalent factor of the given compound (i).

IEFs were determined as the ratio between the EC20 of the references (TCDD, BaP and E2) and those of compound i. IEFs for NPm and 4-t-OP in MELN cells were calculated from data by Pillon et al. ${ }^{50}$. IEFs for PAHs in PLHC-1 cells were calculated from raw data by Louiz et al. ${ }^{44}$ by using the same modelling procedure as for the samples (i.e. by using a maximal effect parameter fixed at $100 \%$ ).

\section{Statistical analysis}

Means of the calculated Cls were compared using a one-way analysis of variance (ANOVA). Assumption tests of normality and equal variance were done before ANOVA. Multiple range tests permitted to pinpoint which sample was different when ANOVA found significant differences between $\mathrm{Cl}$ means. Significance was set at $p<0.05$ in all cases.

\section{Results and discussion}

\section{Deployment of mussels and SPMDs}

\section{Mussels}

The $\mathrm{Cl}$ values (Fig. 2) of the different batches of mussels indicate that mussels were filtering during the exposure time in the lagoons and, therefore, that they could have been exposed to contaminants present in dissolved and particulate phases. Indeed, the Cls of $A L$, ML and TL mussels $(0.16 \pm 0.08 ; 0.15 \pm 0.05$ and $0.21 \pm 0.06$, respectively) were higher than that of control mussels (T0) $(0.12 \pm 0.04)$ although only $\mathrm{Cl}$ increase at TL was statistically significant. The higher $\mathrm{Cl}$ obtained for TL mussels suggests that, in this lagoon, conditions were the most favourable. Nevertheless, mussel mortality was important $(54 \%, 60 \%$ and 45 $\%$ at $\mathrm{AL}, \mathrm{ML}$ and $\mathrm{TL}$, respectively, at the end of the exposure time) as a consequence of the high water temperature observed during that period (up to $25^{\circ} \mathrm{C}$ ). Histology analyses showed that about half of the mussels at T0 and after field exposure were sexually active (Fig. 3).

\section{SPMDS}

As a consequence of the richness of the lagoons, fouling by algae, microorganisms and sediments was observed on the surface of SPMDs at the end of the exposure period. Excessive biofouling does not always result in reduced sampling rates ${ }^{39}$. Indeed, dissipation of phenanthrene d-10 was almost complete at $A L$ and $M L$ (88 and $93 \%$, respectively) implying that the analyte uptake attained the curvilinear stage. The values of the lost rate coefficient $K_{\mathrm{e}}$, calculated from the phenanthrene d-10 dissipation, were of $0.067 \mathrm{~d}^{-1}$ and 0.086 
$d^{-1}$, respectively at $A L$ and $M L$, giving sampling rates for the different target $P A H s$ that ranged from 5 to $16 \mathrm{l} /$ day. Close values of $K_{\mathrm{e}}$ calculated from the phenanthrene d-10, ranging from 0.084 to $0.096 \mathrm{~d}^{-1}$, were estimated for SPMDs deployed for 38- 43 day at sites in the southern North Sea (near-shore and off shore locations) ${ }^{51}$.

\section{PAH and PCB concentrations and EROD activities in sediments, mussels and SPMDs}

\section{PAH distribution in sediments and SPMDs}

The relative percentage of 4-, 5- and 6-ring PAH compounds for each sediment and SPMD extract was calculated in order to determine their distribution in these matrices (Fig. 4 shows the means for the three lagoons). Mussels were not included in this analysis because some PAHs were detected also in mussels before their deployments (T0), thus making it difficult to assess their accumulation patterns.

The standard deviations of PAH distribution in the three lagoons according to their structural features was less important in sediments (<3\%) than in SPMDs (up to $12 \%$ ), indicating that the different PAHs were homogeneously distributed in sediments of the three lagoons. Conversely, higher molecular weight $\mathrm{PAH}$ compounds were more frequently detected in SPMDs from TL than in those from AL and ML.

Higher proportions of 5- and 6-ring PAHs were found in sediments (28 $\pm 3 \%$ and $22 \pm 2 \%$, respectively) than in SPMDs ( $25 \pm 12 \%$ and $6 \pm 5 \%$, respectively). The presence of organic matter in lagoon sediments probably also played an important role in the sorption of hydrophobic compounds. The percentage of total organic carbon was respectively 1.8, 3.9 and $1.9 \%$ for sediments from $\mathrm{AL}, \mathrm{ML}$ and $\mathrm{TL}$.

Inter-site comparison of $P A H$ concentrations

Total PAH concentration in sediments and SPMDs are listed in Table 2. In sediments, total PAH concentrations were higher at ML (977 ng/g d.w.) and TL (1028 ng/g d.w.) than at AL (310 ng/g d.w.). Compared to other Mediterranean sites, the concentrations of ML and TL are higher than those found at the Bizerta lagoon, located in a populated area (Tunisia) (from 83.3 to $447 \mathrm{ng} / \mathrm{g} \mathrm{d}$ d.w.) ${ }^{43-52}$, but are in the range of concentrations found in the Western Mediterranean sea ${ }^{53}$ and are largely lower than those of sediments from heavily polluted sites receiving petroleum, industrial fumes and urban runoff like the Ajaccio Harbour (20440 $\mathrm{ng} / \mathrm{g}$ d.w.) or Toulon (9994 ng/g d.w.) ${ }^{9}$. Whereas PAH concentrations in sediments from the three sites were different, total PAH concentrations in SPMDs were comparable $(141,160$ and $188 \mathrm{ng} / \mathrm{g}$ SPMDs at AL, ML and TL, respectively) and much lower than those found in highly contaminated sites ${ }^{16}$. The aqueous concentration estimated from the in situ PRC calibration (2.9 and $2.5 \mathrm{ng} / \mathrm{l}$ for $\mathrm{AL}$ and $\mathrm{ML}$, respectively) confirmed the low concentration of PAHs in the dissolved phase for these lagoons (Table 3). PAHs sediment-based aqueous concentrations ( $\mathrm{Cw}$ sed) were also estimated (Table 3). $\mathrm{Cw}$ sed for PAHs are several orders of magnitude higher than the estimated PAH Cw spmd concentrations. According to Verweij et al. $^{41}$, this may be due to the inhomogeneous distribution of pollutants in the sediments or due to the fact that some of the assumptions made for the calculation of $\mathrm{C}_{w}$ sed were invalid (the use of Koc values or the assumptions of sorption equilibrium ...). $\mathrm{Cw}_{w}$ spmd certainly gave more realistic estimates of the aqueous pollutant concentrations as accumulation of a compound in SPMDs is mainly governed by a simple partitioning of the compound between SPMD and water. Additionally, we used an in situ calibration. Those $\mathrm{Cw}$ spmd estimated for PAHs are largely lower than the values of the environmental quality standards (EQS) proposed by the European Union (EU) ${ }^{54}$ (Table 3) and the concentration measured for instance in polluted site like oil and gas production areas in the Norwegian sector of the North Sea $(4.3-67 \mathrm{ng} / \mathrm{l}){ }^{55}$ and in the Three Gorges Reservoir (China) $(18-97 \mathrm{ng} / \mathrm{l}){ }^{56}$. Moreover, it is worth noting that few data concerning levels of organic contaminant in SPMDs are available for Mediterranean sites.

$P C B$ concentrations 
Total PCB concentrations were higher in sediments from ML (6 ng/g d.w.) than in those from $\mathrm{AL}$ and TL (4 and $3 \mathrm{ng} / \mathrm{g}$ d.w., respectively) (Table 2). No dioxin-like PCBs (77 and 126) were detected in sediments. In SPMDs, PCB 138 and 153 were identified but not quantified. In mussels from AL and ML, PCB 153 was present at concentrations of 16 and $30 \mathrm{ng} / \mathrm{g} \mathrm{d.w.,}$ respectively. The PCBs present in sediments seemed not to be available to SPMDs, unlike PAHs. However, it should be noted that the limits of quantification are higher for SPMDs than for sediments. Like for PAHs, the PCB concentrations in mussel and sediment extracts from these three lagoons were lower than those measured at polluted sites. For instance, Richardson et al. ${ }^{17}$ found total PCB concentrations up to $425 \mathrm{ng} / \mathrm{g} \mathrm{d} . \mathrm{w}$. in mussels from the coastal waters of Hong-Kong. The PCBs concentrations found in the present study are up to 2- to 3-fold higher, respectively, than the background level determined by Gomez-Gutierrez et al. ${ }^{57}$ from open Mediterranean Sea.

\section{$\mathrm{BaP}$ and TCDD equivalents}

After incubation for $4 \mathrm{~h}$, inductions of EROD activity were observed in PLHC-1 cells exposed to extracts from sediments, mussels and SPMDs from the three lagoons. Bio-BEQ values were higher for sediments (between 547 and $1315 \mathrm{ng} / \mathrm{g}$ d.w.) than for SPMDs (between 69 and $354 \mathrm{ng} / \mathrm{g}$ SPMD) and mussels (between 76 and $101 \mathrm{ng} / \mathrm{g}$ d.w.) (Fig. 5). EROD activities were higher for the sediments of ML than for the sediments of TL and then for the sediments of AL. EROD activities observed in mussels were probably due to the PAH background. However, weaker EROD activities were observed with extracts from mussels exposed in the lagoons than with samples from mussels at T0, suggesting that exposed mussels were in a depuration phase in the field.

After exposure for $24 \mathrm{~h}$, EROD activities could be quantified only in cells incubated with sediments (Fig. 6). Bio-TEQ values ranged from 0.63 to $1.3 \mathrm{ng} / \mathrm{g} \mathrm{d} . \mathrm{w}$. and showed the same trend as the bio-BEQs, i.e., ML>TL>AL. Since PAHs are more readily degraded than dioxins, furans, and coplanar PCBs ${ }^{58}$, the decrease or absence of EROD activities after $24 \mathrm{~h}$ exposure to sediments, mussels and SPMD extracts could be explained by PAH metabolisation in PLHC-1 cells.

Then, in order to determine the relative contribution of PAHs to the EROD activities, we calculated the chem-BEQs and chem-TEQs by using IEF of active PAHs ${ }^{44-6}$ and the data obtained with the chemical analysis (Fig. 5). The PAHs identified by chemical analysis explained the EROD activities observed in PLHC-1 cells after $4 \mathrm{~h}$ exposure in a proportion that ranged from 56 to $97 \%$ for SPMDs and 49 to $86 \%$ for sediments. After $24 \mathrm{~h}$ exposure, the chem-TEQs explained only between 4 and $18 \%$, (average $=11 \pm 7 \%$ ) of the EROD activities observed in sediments (Fig. 6). Although we did not detect dioxin-like PCBs, the presence of PCB 138 and 153 in sediments, generally used as indicators of contamination by halogenated aromatic hydrocarbons (HAHs), suggests that other active HAHs such as polychlorinated dibenzo-p-dioxins (PCDDs) and polychlorinated dibenzofurans (PCDFs), which were not identified by chemical analysis, were present in the extracts and were responsible for part of the biological response ${ }^{20}$.

\section{ER ligands and Estrogenic activities in sediments, mussels and SPMDs}

\section{AP concentrations}

AP concentrations reached 164 and $660 \mathrm{ng} / \mathrm{g}$ d.w. in AL and ML sediments, probably as a consequence of the wastewater inputs from STPS. Previous studies have shown that APS can be found abundantly in sediments and organisms impacted by wastewater from STPS ${ }^{59-}$ 60-61. NPm were bioaccumulated in mussels (1173 and $3518 \mathrm{ng} / \mathrm{g} \mathrm{d.w}$. in AL and ML extracts, respectively). Similar NPm concentrations in bivalves' tissue and comparable NPm partitions between biota and sediments have been observed by Cheng et al. ${ }^{61}$ at the coast of Taïwan 
(i.e., $190 \mathrm{ng} / \mathrm{g}$ d.w. in sediments and $5190 \mathrm{ng} / \mathrm{g}$ d.w. in cultivated oyster). In comparison with APs concentrations reviewed by David et al. ${ }^{62}$ in marine environments, the concentrations that we observed in mussels are among the highest found in the literature. NPm could be quantified in the SPMDs exposed in ML at a concentration of $234 \mathrm{ng} / \mathrm{g}$ SPMD. The estimated aqueous concentrations of NPm using equation (1) and calibration data from Huckins et al. ${ }^{37}$ was $8.3 \mathrm{ng} / \mathrm{l}$, which is lower than the $300 \mathrm{ng} / \mathrm{l}$ proposed by EU EQS. However, this estimated value has to be taken with precaution as Harman et al. ${ }^{63}$ failed to estimate sampling rates of APs in a laboratory exposure study with seawater using the equation and calibration data from Huckins et al. ${ }^{37}$ based on calibration studies with PCBs, PAHs and PCDDs/PCDFs. E2 equivalents (EEQs)

Estrogenic activities were detected in mussel, SPMD and sediment and could be quantified in mussel and in sediment extracts from ML and TL (Fig. 7). However, we did not present EEQs results from mussels because, as suggested by Bayen et al. ${ }^{64}$ and David et al. ${ }^{65}$, the high estrogenic activities observed could also be due to the presence of endogenous ER ligands (although involvement of estrogenic steroids in the reproduction of mollusc bivalves has not yet been confirmed). Bio-EEQs were higher in sediments than in SPMDs. For sediments, bio-EEQ values were $2710 \mathrm{pg}$ EEQs/g d.w. with ML extracts and $190 \mathrm{pg}$ EEQs/g d.w. with TL extracts. Estrogenic activities were lower than $450 \mathrm{pg}$ EEQs/g SPMD in all SPMDs.

It has been shown that, in the case of contamination by wastewater effluents, APs can account for a large part of the overall observed estrogenic activity ${ }^{20}$. We therefore calculated the chem-EEQs from the AP (4tOP and NPm) concentrations measured in sediment and SPMD extracts (chem-EEQs) and compared them with the bio-BEQs. The chem-EEQs slightly explain the overall estrogenic activities, as APs accounted for $3 \%$ of the estrogenic activity of ML sediments. Therefore, other not analysed ER ligands are present in the extracts. Environmental estrogens, such as natural and synthetic steroids, can be suspected because they have been found to accumulate in surface sediments around STP discharges 66-67-68. The range of EEQs concentrations found in lagoon sediments is close to that of sediments related to wastewater discharges from STPs, like those from English estuaries ${ }^{69}$ and Dutch inland waters ${ }^{70}$.

\section{Conclusion}

The aim of this study was to investigate the distribution of ER and AhR activators in the particular context of Mediterranean coastal lagoons. Two of these Mediterranean coastal lagoons received effluents from STPs and contain organic pollutants in their sediments. The organic pollution input was therefore hypothesised to come mainly from sediments resuspension. We indeed observed that sediments actively contribute to the contamination of water. This contribution is especially important for APs at $A L$ and $M L$, the two lagoons that were impacted by wastewater effluents. NPm, generally considered as a good tracer of sewage impacted environment, could be quantified in sediments, SPMD and mussels. The concentrations observed in mussels were among the highest found in the literature. The high AP concentrations found in mussels indicate that high quantities of particulate contaminants are present in water. PAH pollution is high in sediments but aqueous $\mathrm{PAH}$ concentrations were low and below the values that induce adverse effects according to the Environmental Quality Standards of the Water Framework Directive. Dioxin-like activities were observed in sediments but we did not observe contamination by dioxin-like compounds in mussels and SPMDs. Organisms present in these lagoons are exposed to organic contaminants, especially to APs which are endocrine disruptors. High levels are present in the particulate phase, however, it would be important to know if the aqueous concentrations are able to cause disruption for organisms. 


\section{Acknowledgements}

The authors wish to thank E. Maillot-Marechal and A. Znidah for help with the experimental work. They would also like to thank the staff of the Ifremer Coastal Laboratories in Sete for samplings. A. David is a PhD student supported by a studentship from the French Research Ministry. This work was funded by PNRPE (French Endocrine Disrupter Research Programme) and ERICHE (Evaluate and Reduce Impact of Chemistry on Environment) network.

\section{References}

1 S. Bayen, Y. Gong, H. S. Chin, H. K. Lee, Y. E. Leong, J. P. Obbard, Environ. Health Perspect., 2004, 112, 1467-1471.

2 M. A. Blackburn, M. J. Waldock, Wat. Res., 1995, 29, 1623-1629.

3 K. Bester, N. Theobald, H. F. Schroder, Chemosphere, 2001, 45, 817-826.

4 D. Y. Shang, R. W. Macdonald, M. G. Ikonomou, Environ. Sci. Technol., 1999, 33, 13661372.

5 T. Isobe, H. Nishiyama, A. Nakashima, H. Takada, Environ. Sci. Technol., 2001, 35, 10411049.

6 A. David, E. Gomez, S. Aït-Aïssa, Rosains D., C. Casellas, H. Fenet, Arch. Environ. Contam. Toxicol., 2010, 58, 562-575.

7 H. F. Prest, B. J. Richardson, L. A. Jacobson, J. Vedder, M. Martin, Mar. Pollut. Bull., 1995, 30, 543-554.

8 C. S. Peven, A. D. Uhler, F. J. Querzoli, Environ. Toxicol. Chem., 1996, 15, 144-149.

9 P. Baumard, H. Budzinski, P. Garrigues, Environ. Toxicol. Chem., 1998, 17, 765-776.

10 B. Andral, J. Y. Stanisiere, D. Sauzade, E. Damier, H. Thebault, F. Galgani, P. Boissery, Mar. Pollut. Bull., 2004, 49, 704-712.

11 J. J. Stegeman, J. J. Lech, Environ. Health Perspect., 1991, 90, 101-109.

12 J. N. Huckins, M. W. Tubergen, G. K. Manuweera, Chemosphere, 1990, 20, 533-552.

13 J. Axelman, K. Naes, C. Näf, D. Broman, Environ. Toxicol. Chem., 1999, 18, 2454-2461.

14 B. J. Richardson, G. J. Zheng, E.S.C Tse, S. B. De Luca-Abbott, S. Y. M. Siu, P. K. S Lam, Environ. Pollut., 2003, 122, 223-227.

15 T. Baussant, S. Sanni, G. Jonsson, A. Skadsheim, J. F. Børseth, Environ. Toxicol. Chem., 2001, 20, 1175-1184.

16 P. D. Boehm, D. S Page, J.S. Brown, J. M. Neff, A. E. Bence, Mar. Pollut. Bull., 2005, 50, 740-750.

17 B. J. Richardson, G. J. Zheng, E. S. C. Tse, P. K. S. Lam, Chemosphere 2001, 45, 12011208.

18 K. Booij, B. N. Zegers, J. P. Boon, Chemosphere, 2002, 46, 683-688.

19 E. J. Routledge, J. P.Sumpter Environ. Toxicol. Chem., 1996, 15, 241-248.

20 C. H. Koh, J. S. Khim, D. L. Villeneuve, K. Kannan, B. G. Johnson, J. P. Giesy, Ecotoxicol. Environ. Saf., 2005, 61, 366-379.

21 A. M. Soto, H. Justicia, J. W.Wray, C. Sonnenschein, Environ. Health Perspect., 1991, 92, $167-173$

22 A. M. Soto, C. Sonnenschein, K. L. Chung, M. F. Fernandez, N. Olea, F. O.Serrano, Environ. Health Perspect., 1995, 103, 113-122.

23 M. Van den Berg, L. Birnbaum, A. T. C. Bosveld, B. Brunstrom, P. M. Cook, M. Feeley, P. Giesy, A. Hanberg, R. Hasegawa, S. W. Kennedy, T. Kubiak, J. C. Larsen, F. X. R. van Leeuwen, A. K. D. Liem, C. Nolt, R. E. Peterson, L. Poellinger, S. Safe, D. Schrenk, D. Tillitt, M. Tysklind, M. Younes, F. Waern, T. Zacharewski, Environ. Health Persp., 1998, 106, 775792.

24 K. Fent, R. Bätscher, Environ. Toxicol. Chem., 2000, 19, 2047-2058. 
25 J. A. Lebo, J. L. Zajicek, J. N. Huckins, J.D. Petty, P. H. Peterman, Chemosphere, 1992, 25, 697-718.

26 R. W. Gale, J. N. Huckins, J. D. Petty, P. H. Peterman, L. L. Williams, D. Morse, T. R. Schwartz, D. E. Tillitt, Environ. Sci. Technol., 1997, 31, 178-187.

27 G. Gilli, T. Schilirò, C. Pignata, D. Traversi, E. Carraro, C. Baiocchi, R. Aigotti, D. Giacosa, E. Fea, Chemosphere, 2005, 61, 1691-1699.

28 R. Ke, J. Li, M. Qiao, Y. Xu, Z. Wang, Arch. Environ. Contam. Toxicol., 2007, 53, 313-320. 29 A.C. Rastall, D. Getting, J. Goddard, D.R. Roberts, L. Erdinger, Environ. Sci. Pollut. Res. Internat., 2006, 13, 256-267.

30 M. Plus, I. L. Jeunesse, F. Bouraoui, J-M. Zaldívar, A. Chapelle, P. Lazure, Proceedings of the conference on Southern European Coastal Lagoons, Ferrara, 2003.

31 P. Lazure, Vie et Milieu, 1992, 42, 137-145.

32 S. Gauthier-Clerc, J. Pellerin, C. Blaise, F. Gagne, Comp. Biochem. Physiol. C Toxicol. Pharmacol., 2002, 131, 457-467.

33 EPA Method 3640 A, Gel-Permeation Clean-up.

34 J.N. Huckins, J.D. Petty, H.F. Prest, R.C. Clark, D.A. Alvarez, C.E. Orazio, J.A. Lebo., W.L. Cranor, B.T. Johnson, API publication 4690. American Petroleum Institute, Washington, DC., 2002.

35 V. Yusa, A. Pastor and M. de la Guardia, Anal. Chim. Acta, 2005, 540, 355-366.

36 K. Booij, H. E. Hofmans, C. V. Fischer, E. M. Van Weerlee, Environ. Sci. Technol., 2003, 37, 361-366.

37 J. Huckins, J. D. Petty, K. Booij, Springer, New York, 2006, 223 pp.

38 K. Booij, H. M. Sleiderink, F. Smedes, Environ. Toxicol. Chem., 1998, 17, 1236-1245.

39 K. Booij, R. van Bommel, A. Mets, R. Dekker, Chemosphere, 2006, 65, 2485-92.

40 B.J. Richardson, P. K. S. Lam, G. J. Zheng G, K. E. McClellan, S. B. De Luca-Abbott, Mar. Pollut. Bull., 2002, 44, 1372-1379.

41 F. Verweij, K. Booij, K. Satumalay, N. van der Molen and R. van der Oost, Chemosphere, 2004, 54, 1675-1689.

42 M.D. Di Toro, C.S. Zarba, D.J. Hansen, W.J. Berry, R.C. Swartz, C.E. Cowan, S.P. Pavlou, H.E. Allen, N.A. Thomas, P.R. Paquin, Environ. Toxicol. Chem., 1991, 10, 15411583.

43 S.W. Karickhoff, Chemosphere, 1981, 10, 833-846.

44 I. Louiz, S. Kinani, M. E. Gouze, M. Ben-Attia, D. Menif, S. Bouchonnet, J. M. Porcher, O. K. Ben-Hassinea, S. Aït-Aïssa, Sci. Total Environ., 2008, 402, 318-29.

45 N. Laville, S. Ait-Aissa, E. Gomez, C. Casellas, J. M. Porcher, Toxicology, 2004, 196, 4155.

46 P. Balaguer, F. François, F. Communal, H. Fenet, A-M. Boussioux, M. Pons, J. C. Nicolas, C. Casellas, Sci. Tot. Environ., 1999, 233, 47-56.

47 T. Mosmann, J. Immunol. Methods, 1983, 65, 55-63.

48 E. Vindimian, C. Robaut, G. Fillion, J. Appl. Biochem., 1983, 5, 261-268.

49 D. L. Villeneuve, A. L. Blankenship, J. P.Giesy, Environ. Toxicol. Chem., 2000, 19, 28352843.

50 A. Pillon, A. M. Boussioux, A. Escande, S. Ait-Aissa, E. Gomez, H. Fenet H, M. Ruff, D. Moras, F. Vignon, M-J. Duchesne, C. Casellas, J.-C. Nicolas, P. Balaguer, Environ. Health Persp., 2005, 113, 278-284.

51 K. Booij, F. Smedes, E. M. Van Weerlee and P. J. C. Honkoop, Environ. Sci. Technol., 2006, 40 (12), 3893-3900.

52 S. Trabelsi, M. R. Driss, Mar. Pollut. Bull., 2005, 50, 344-348.

53 E. Lipiatou, A. Saliot, Mar. Chem., 1991, 32, 51-71.

54 European Commission, report COM(2006) 397 final, 2006

55 G. Durell, T. R. Utvik, S. Johnsen, T. Frost, J. Neff, Mar. Environ.Res., 2006, 62, 194223.

56 J. Wang, Y. Bi, G. Pfister, B. Henkelmann, K. Zhu, K-W. Schramm, Chemosphere, 2009, 75, 1119-1127 
57 A. Gomez-Gutierrez, E. Garnacho, J. M. Bayona, J. Albaiges, Environ. Pollut., 2007, 148, 396-408.

58 M. Celander, J. Bremer, M. E. Hahn, J. J. Stegeman, Environ. Toxicol. Chem., 1997, 16, 900-1007.

59 P. L. Ferguson, C. R. Iden, B. J. Brownawell, Environ. Sci. Technol., 2001, 35, 24282435.

60 M. Petrovic, A. R. Fernandez-Alba, F. Borrull, R. M. Marce, M. E. Gonzalez, D. Barcelo, Environ. Toxicol. Chem., 2002, 21, 37-46.

61 C. Y. Cheng, L. L.Liu, W. H. Ding, Chemosphere, 2006, 65, 2152-2159.

62 A. David, H. Fenet, E. Gomez, Mar. Pollut. Bull., 2009, 58, 953-960.

63 C. Harman, K. E. Tollefsen, O. Boyum, K. Thomas, M. Grung, Chemosphere, 2008, 72, 1510-1516.

64 S. Bayen, Y. Gong, H. S. Chin, H. K. Lee, Y. E. Leong, J. P. Obbard, Environ. Health Perspect., 2004, 112, 1467-1471.

65 A. David, H. Fenet, A. Escande, D. Munaron, D. Rosain, E. Maillot-Maréchal, S. Aït-Aïssa, C. Casellas and E. Gomez. Environ. Toxicol., DOI 10.1002/tox.20613, in press.

66 M. Peck, R. W. Gibson, A. Kortenkamp, E. M. Hill, Environ. Toxicol. Chem., 2004, 23, 945-952.

67 T. Isobe, S. Serizawa, T. Horiguchi, Y. Shibata, S. Managaki, H. Takada, M. Morita, H. Shiraishi, Environ. Pollut., 2006, 144, 632-638.

68 S. Kinani, S. Bouchonnet, N. Creusot, S. Bourcier, P. Balaguer, J. M. Porcher JM, S. AïtAïssa, Environ. Pollut., 2010, 158, 74-83.

69 K. V. Thomas, J. Balaam, M. R. Hurst, J. E. Thain, Environ. Toxicol. Chem., 2004, 23, 1156-1163.

70 C. J. Houtman, P. Booij, E. Jover, D. P. Del Rio, K. Swart, M. Van Velzen, R. Vreuls, J. Legler, A. Brouwer, M.H. Lamoree, Chemosphere, 2006, 65, 2244-2252. 
Table 1: The molar masses, partition coefficients (log Kow), and limit of quantification (LQ) expressed in ng/g dry weight d.w. for sediments and mussels and ng/g SPMD for SPMDs.

\begin{tabular}{|c|c|c|c|c|c|}
\hline & Molar mass & Log Kow & $\begin{array}{l}\text { LQ sediment } \\
\text { (ng/g d.w.) }\end{array}$ & $\begin{array}{l}\text { LQ mussels } \\
\text { (ng/g d.w.) }\end{array}$ & $\begin{array}{c}\text { LQ SPMDS } \\
\text { (ng/g SPMD) }\end{array}$ \\
\hline Phenanthrene (Phe) & 178 & 4.5 & 0.7 & 2.6 & 1.5 \\
\hline Anthracene (Ant) & 178 & 4.4 & 0.7 & 2.6 & 1.5 \\
\hline Fluoranthene (Flt) & 202 & 4.9 & 0.7 & 2.6 & 1.5 \\
\hline Pyrene (Pyr) & 202 & 4.9 & 0.7 & 2.6 & 1.5 \\
\hline Benzo[a]anthracene (B(a)A) & 228 & 5.6 & 0.7 & 2.6 & 1.5 \\
\hline Chrysene (Chr) & 228 & 5.2 & 0.7 & 2.6 & 1.5 \\
\hline Benzo[b]fluoranthene $(\mathrm{B}(\mathrm{b}) \mathrm{F})$ & 252 & 6.0 & 0.7 & 2.6 & 1.5 \\
\hline Benzo[k]fluoranthene $(\mathrm{B}(\mathrm{k}) \mathrm{F})$ & 252 & 6.1 & 0.7 & 2.6 & 1.5 \\
\hline Benzo[a]pyrene $(B(a) P)$ & 252 & 6.1 & 2.6 & 9.6 & 5.3 \\
\hline Indeno[1,2,3-cd]pyrene (Ind) & 276 & 6.6 & 2.6 & 9.6 & 5.3 \\
\hline Dibenz[a,h]anthracene (DBA) & 276 & 6.5 & 2.6 & 9.6 & 5.3 \\
\hline Benzo[ghi]perylene (B[ghi]P) & 276 & 6.8 & 2.6 & 9.6 & 5.3 \\
\hline PCB 28 & 257 & 5.6 & 0.8 & 3.1 & 1.7 \\
\hline PCB 52 & 292 & 6.1 & 0.8 & 3.1 & 1.7 \\
\hline PCB 77 & 292 & 6.9 & 0.7 & 2.6 & 1.4 \\
\hline PCB 101 & 326 & 6.4 & 0.8 & 3.2 & 1.7 \\
\hline PCB 126 & 326 & 6.9 & 0.7 & 2.6 & 1.4 \\
\hline PCB 138 & 361 & 6.7 & 0.8 & 3.1 & 1.7 \\
\hline PCB 153 & 361 & 6.9 & 0.8 & 3.2 & 1.8 \\
\hline РCB 180 & 395 & 7.2 & 0.8 & 3.2 & 1.7 \\
\hline $4 \mathrm{tOP}$ & 206 & 4.1 & 9.1 & 34.1 & 18.9 \\
\hline $\mathrm{NPm}$ & 220 & 4.5 & 12.1 & 45.5 & 25.3 \\
\hline \multicolumn{6}{|l|}{ Bioassays } \\
\hline E2 EQ on MELN & & & 0.1 & & 0.5 \\
\hline BaP EQ on PLHC-1 (4h) & & & 4.2 & 21.0 & 21.0 \\
\hline TCDD EQ on PLHC-1 (24h) & & & 0.3 & 1.4 & 1.4 \\
\hline
\end{tabular}


Table 2: PAH, PCB and alkylphenol concentrations in sediments in $\mathrm{ng} / \mathrm{g}$ dry weight (results of two extractions), mussels in ng/g dry weight and SPMDs in ng/g SPMD for AL, ML and TL.

\begin{tabular}{|c|c|c|c|c|c|c|c|c|c|c|c|c|c|}
\hline & \multicolumn{6}{|c|}{ Sediments } & \multicolumn{4}{|c|}{ Mussels } & \multicolumn{3}{|c|}{ SPMDs } \\
\hline & \multicolumn{2}{|c|}{$\mathrm{AL}$} & \multicolumn{2}{|c|}{$\mathrm{ML}$} & \multicolumn{2}{|c|}{$\mathrm{TL}$} & \multirow[t]{2}{*}{ T0 } & \multirow[t]{2}{*}{$\mathrm{AL}$} & \multirow[t]{2}{*}{$\mathrm{ML}$} & \multirow[t]{2}{*}{$\mathrm{TL}$} & \multirow[t]{2}{*}{$\mathrm{AL}$} & \multirow[t]{2}{*}{$\mathrm{ML}$} & \multirow[t]{2}{*}{$\mathrm{TL}$} \\
\hline & 1 & 2 & 1 & 2 & 1 & 2 & & & & & & & \\
\hline Phe & 19 & 21 & 49 & 60 & 40 & 42 & - & - & - & - & 8 & 6 & 7 \\
\hline Ant & 7 & 5 & 15 & 23 & 13 & 13 & - & - & - & - & $<\mathrm{LD}$ & $<\mathrm{LD}$ & $<L D$ \\
\hline Flt & 46 & 38 & 134 & 126 & 127 & 102 & - & - & - & - & 26 & 39 & 21 \\
\hline Pyr & 37 & 29 & 115 & 100 & 136 & 105 & - & - & - & - & 26 & 34 & 23 \\
\hline$B(a) A$ & 21 & 17 & 68 & 70 & 84 & 59 & - & - & - & - & 14 & 15 & 19 \\
\hline Chr & 24 & 19 & 72 & 67 & 78 & 55 & - & - & - & - & 17 & 19 & 16 \\
\hline$B(b) F$ & 41 & 37 & 119 & 97 & 157 & 126 & - & - & - & - & 19 & 21 & 21 \\
\hline$B(k) F$ & 10 & 12 & 34 & 29 & 47 & 37 & - & - & - & - & $<$ LD & $<$ LD & 18 \\
\hline$B(a) P$ & 29 & 29 & 81 & 93 & 111 & 102 & - & - & - & - & $<$ LD & 15 & 16 \\
\hline Ind & 27 & 43 & 100 & 116 & 139 & 135 & - & - & - & - & $<\mathrm{LQ}$ & $<\mathrm{LQ}$ & 20 \\
\hline DBA & 6 & 10 & 18 & 32 & 35 & 30 & - & - & - & - & $<$ LQ & $<$ LQ & 16 \\
\hline B[ghi]P & 25 & 37 & 90 & 90 & 133 & 95 & - & - & - & - & 13 & $<\mathrm{LQ}$ & $<\mathrm{LQ}$ \\
\hline$\sum$ HAPS & 303 & 316 & 920 & 1032 & 1119 & 934 & - & - & - & - & 141 & 160 & 188 \\
\hline РCB 28 & $<\mathrm{LD}$ & $<\mathrm{LD}$ & $<$ LD & 1 & 1 & 1 & $<L D$ & $<\mathrm{LD}$ & $<$ LD & $<\mathrm{LD}$ & $<\mathrm{LQ}$ & $<\mathrm{LQ}$ & $<\mathrm{LQ}$ \\
\hline PCB 52 & $<L D$ & $<\mathrm{LD}$ & $<$ LD & $<L Q$ & $<$ LD & $<$ LD & $<L D$ & $<L D$ & $<\mathrm{LD}$ & $<L D$ & $<L Q$ & $<L Q$ & $<$ LQ \\
\hline PCB 77 & $<$ LD & $<$ LD & $<$ LD & $<$ LD & $<$ LD & $<$ LD & $<L D$ & $<L D$ & $<$ LD & $<$ LD & $<$ LD & $<$ LD & $<$ LD \\
\hline РCВ 101 & $<\mathrm{LD}$ & $<L D$ & 1 & $<\mathrm{LQ}$ & $<\mathrm{LD}$ & $<L D$ & $<L D$ & $<L D$ & $<\mathrm{LD}$ & $<\mathrm{LD}$ & $<L D$ & $<$ LD & $<\mathrm{LD}$ \\
\hline РСВ 126 & $<$ LD & $<$ LD & $<L D$ & $<$ LD & $<$ LD & $<$ LD & $<L D$ & $<L D$ & $<$ LD & $<$ LD & $<$ LD & $<$ LD & $<$ LD \\
\hline PCB 138 & 1 & 2 & 2 & 3 & $<\mathrm{LQ}$ & $<L Q$ & $<L D$ & $<L D$ & $<L D$ & $<L D$ & $<L Q$ & $<L Q$ & $<\mathrm{LQ}$ \\
\hline PCB 153 & 1 & 2 & 2 & 3 & 1 & 1 & $<L D$ & 16 & 30 & $<L Q$ & $<L Q$ & $<L Q$ & $<$ LQ \\
\hline РCB 180 & $<\mathrm{LQ}$ & 2 & 1 & 3 & $<L Q$ & $<L Q$ & $<L D$ & $<\mathrm{LD}$ & $<L D$ & $<L D$ & $<$ LD & $<$ LD & $<$ LD \\
\hline$\sum$ PCBs & 2 & 6 & 6 & 10 & 3 & 3 & $<L D$ & 16 & 30 & $<L D$ & $<L Q$ & $<L Q$ & $<$ LQ \\
\hline $4 \mathrm{tOP}$ & $<$ LQ & $<$ LQ & $<L Q$ & $<L Q$ & $<L D$ & $<L D$ & $<L D$ & 384 & 376 & $<L Q$ & $<$ LD & $<L D$ & $<$ LD \\
\hline NPm & 164 & 35 & 660 & 597 & $<L D$ & $<L D$ & $<L D$ & 1173 & 3518 & $<$ LD & $<$ LD & 234 & $<$ LD \\
\hline$\%$ TOC & & & & & & & & & & & & & \\
\hline
\end{tabular}


Table 3: Polycyclic aromatic hydrocarbon (PAH) concentrations in water of $A L M L$ and $T L$ estimated from semipermeable membrane devices (SPMDs) data $\left(\mathrm{C}_{\mathrm{w} \text { SPMD }} \mathrm{ng} / \mathrm{l}\right)$ and sediment data $\left(\mathrm{C}_{\mathrm{w} \text { sed }} \mathrm{ng} / \mathrm{l}\right)$.

\begin{tabular}{lcccccc}
\hline & \multicolumn{3}{c}{$\mathrm{C}_{\text {wSPMD }}$} & \multicolumn{3}{c}{$\mathrm{C}_{\mathrm{w} \text { sed }}$} \\
& $\mathrm{AL}$ & $\mathrm{ML}$ & $\mathrm{TL}$ & $\mathrm{AL}$ & $\mathrm{ML}$ & $\mathrm{TL}$ \\
\cline { 2 - 7 } Phe & 0.28 & 0.20 & - & 61 & 166 & 124 \\
Ant & $<\mathrm{LQ}$ & $<\mathrm{LQ}$ & - & 18 & 58 & 41 \\
Flt & 0.44 & 0.56 & - & 116 & 360 & 317 \\
Pyr & 0.43 & 0.45 & - & 91 & 298 & 335 \\
B(a)A & 0.22 & 0.20 & - & 45 & 166 & 174 \\
Chr & 0.27 & 0.24 & - & 56 & 183 & 175 \\
B(b)F & 0.30 & 0.26 & - & 87 & 243 & 318 \\
B(k)F & $<$ LQ & $<$ LQ & - & 25 & 70 & 94 \\
B(a)P & $<$ LQ & 0.21 & - & 64 & 194 & 239 \\
Ind & $<$ LQ & $<$ LQ & - & 72 & 223 & 282 \\
DBA & $<$ LQ & $<$ LQ & - & 17 & 51 & 68 \\
B[ghi]P & 0.32 & $<$ LQ & - & 62 & 178 & 225 \\
IHAPS & 2.93 & 2.50 & - & 768 & 2482 & 2480 \\
\hline
\end{tabular}




\section{Figures}

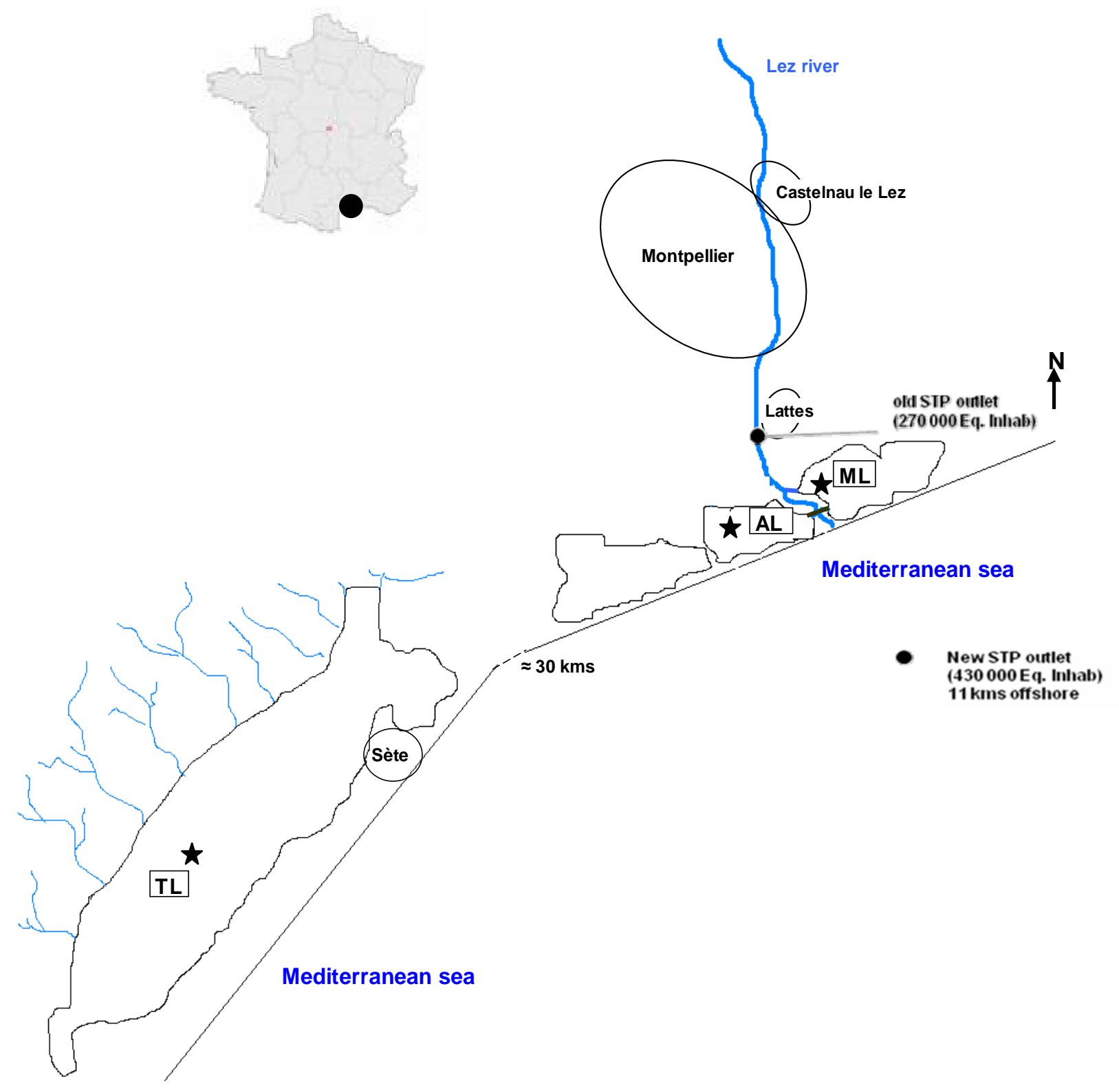

Fig. 1: Schema of the study area and the 3 sampling sites $\left(^{*}\right)$ located in the Arnel $(A L)$, Méjean (ML) and Thau (TL) lagoons. STP means sewage treatment process. 


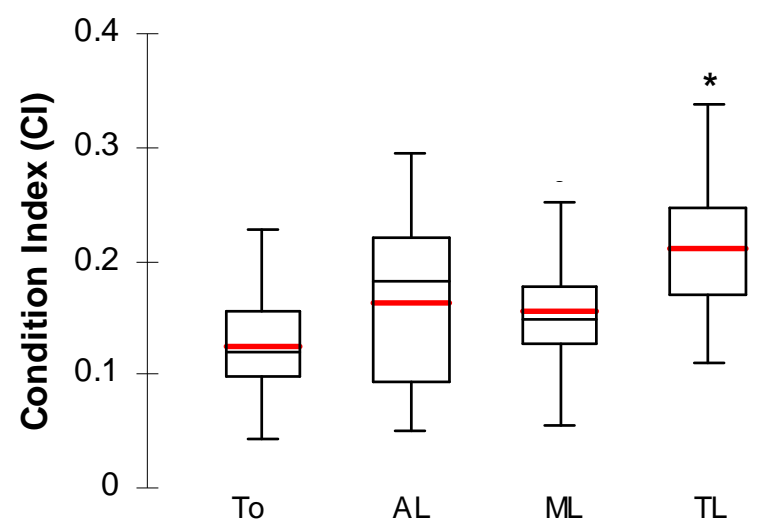

Fig. 2: Condition index (Cl) of mussels of the control batch (T0) and mussels collected after

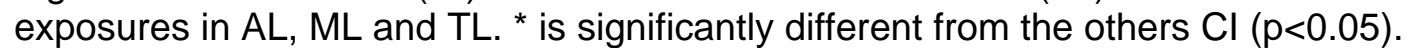

Box-and-whiskers-plots, with length of each box corresponding to the interquartile range, the upper and lower boundary of the box representing 75th and $25^{\text {th }}$ percentiles, respectively. The line in the box indicates the median value and the bold line, the mean value. 


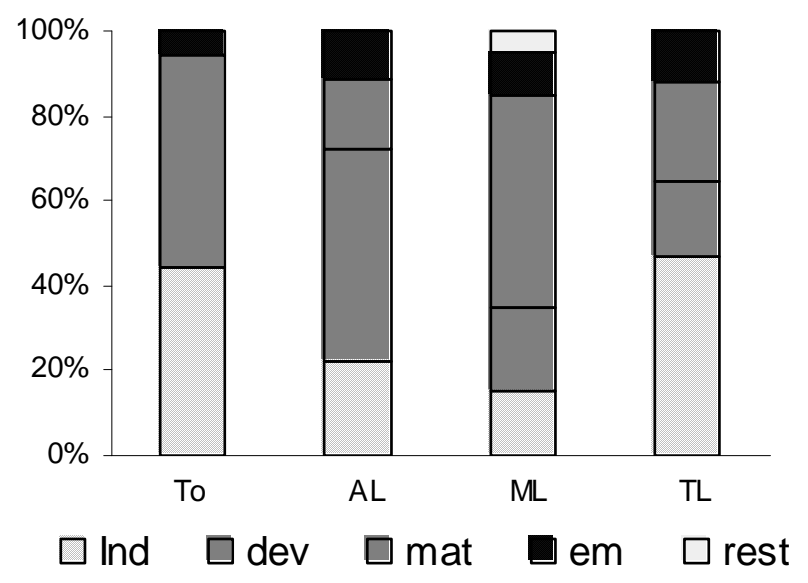

Fig. 3: Percentage of the different development stages observed for mussels on the control batch (TO) and one month after exposure in AL, ML and TL. Ind = indifferent stage; dev = development stage; mat = mature stage $;$ em = emission stage . 


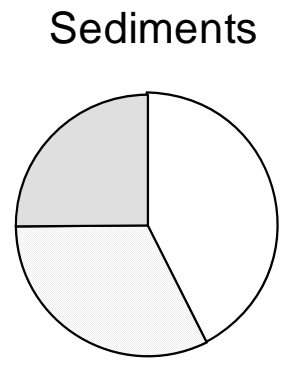

SPMDS

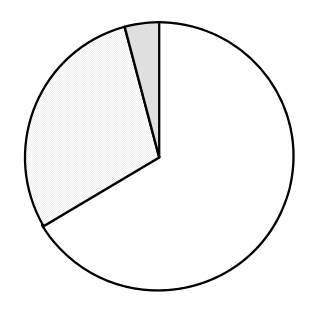

$\square$ 4-ring $\square$ 5-ring $\square 6$-ring

Fig. 4: The relative average percentage for the 3 lagoons of PAHs according to their structural features in sediments and SPMDs of $A L, M L$ and $T L$. 


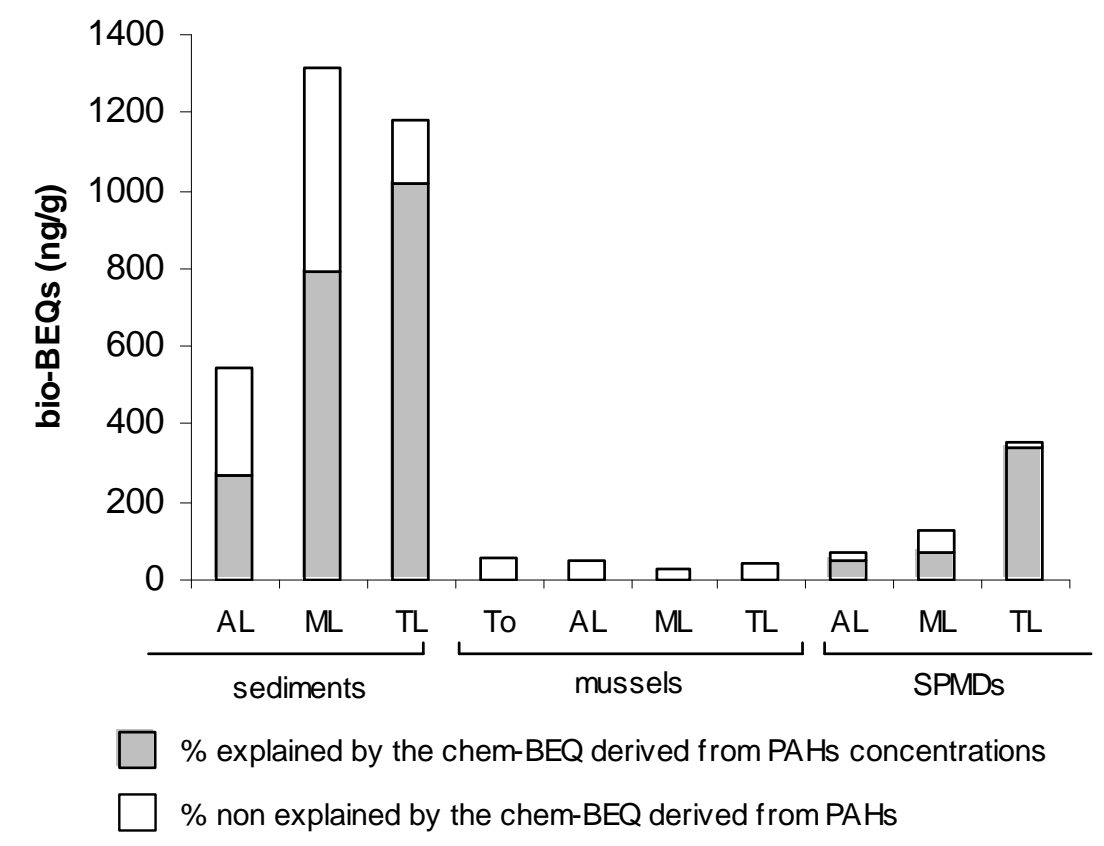

Fig. 5: BaP equivalents (BEQs) derived from bioassays ( $4 \mathrm{~h}$ exposure in PLHC-1 cells) and the percentage explained by the BaP equivalents derived from PAHs concentrations (chemBEQS) for sediments, mussels and SPMDs of AL, ML and TL. 


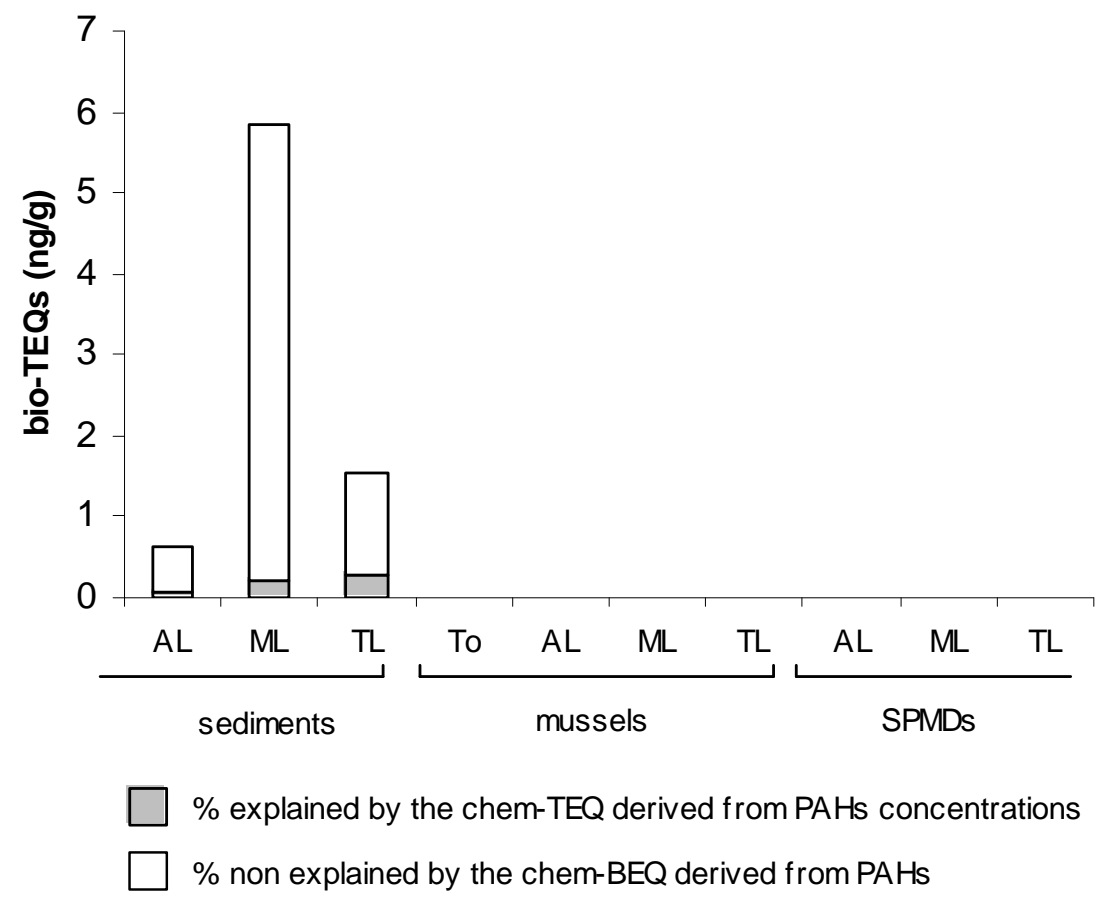

Fig. 6: TCDD equivalents (TEQs) derived from bioassays (24 $\mathrm{h}$ exposure in PLHC-1 cells) and the percentage explained by the TCDD equivalents derived from PAHs concentrations (chem-TEQs) for sediments, mussels and SPMDs of AL, ML and TL. 


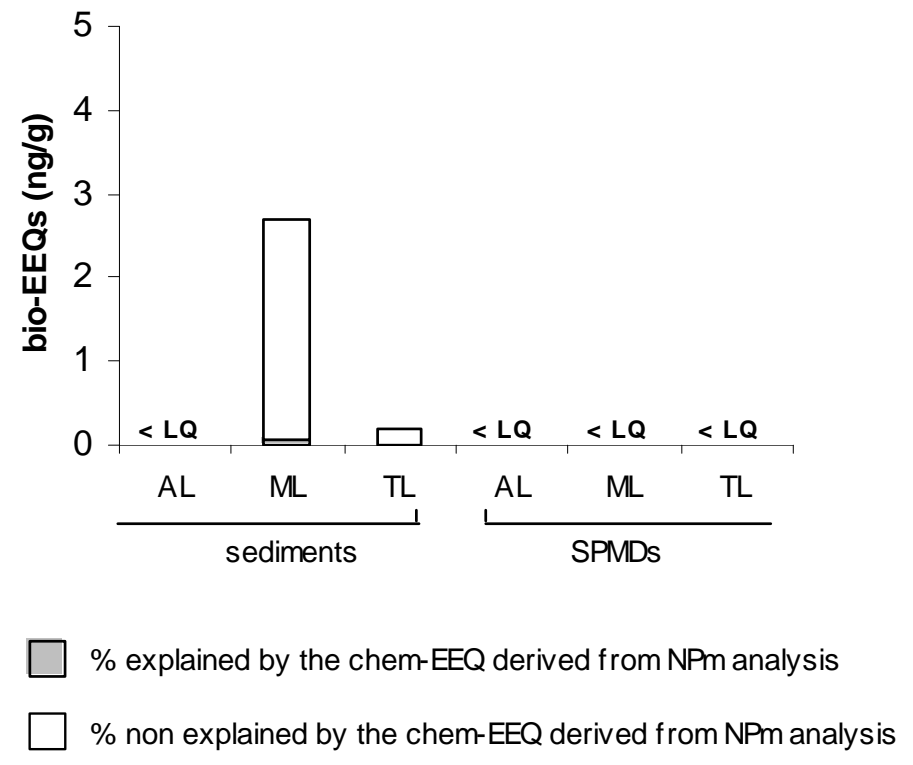

Fig. 7: E2 equivalents (EEQs) derived from the bioassays (bio-EEQs) and the percentage explained by the E2 equivalents derived from nonylphenols concentrations (chem-EEQs) for sediments and SPMDs of AL, ML and TL. 